\title{
Apomorphine in the treatment of Parkinson's disease: a review
}

\author{
O uso da apomorfina no tratamento da doença de Parkinson: revisão da literatura \\ Renata Ramina Pessoa ${ }^{1}$, Adriana Moro ${ }^{1,2}$, Renato Puppi Munhoz ${ }^{3}$, Hélio A.G. Teive ${ }^{4}$, Andrew J. Lees ${ }^{5}$
}

\begin{abstract}
Optimizing idiopathic Parkinson's disease treatment is a challenging, multifaceted and continuous process with direct impact on patients' quality of life. The basic tenet of this task entails tailored therapy, allowing for optimal motor function with the fewest adverse effects. Apomorphine, a dopamine agonist used as rescue therapy for patients with motor fluctuations, with potential positive effects on nonmotor symptoms, is the only antiparkinsonian agent whose capacity to control motor symptoms is comparable to that of levodopa. Subcutaneous administration, either as an intermittent injection or as continuous infusion, appears to be the most effective and tolerable route. This review summarizes the historical background, structure, mechanism of action, indications, contraindications and side effects, compares apomorphine infusion therapy with other treatments, such as oral therapy, deep brain stimulation and continuous enteral infusion of levodopa/carbidopa gel, and gives practical instructions on how to initiate treatment.
\end{abstract}

Keywords: Apomorphine; dopaminer agents; Parkinsons disease; review.

\section{RESUMO}

A optimização do tratamento da doença de Parkinson idiopática se faz um desafio, pois tem impacto direto na qualidade de vida do paciente. 0 melhor esquema terapêutico é o que permite o melhor controle motor com os menores efeitos adversos, através de terapêutica individualizada. A apomorfina é o único medicamento antiparkinsoniano que pode ser comparável à potência da levodopa no controle dos sintomas motores. Trata-se de um agonista dopaminérgico empregado na terapia de resgate em pacientes com flutuações motoras e também contribui para a melhora de muitos sintomas não motores. A via subcutânea, com injeções intermitentes, ou com infusão contínua, parece ser a melhor opção pela eficácia e tolerabilidade. Essa revisão resume aspectos históricos, estrutura da molécula, mecanismo de ação, indicação, contra-indicação e efeitos colaterais, compara a terapia de infusão com apomorfina com outros tratamentos, como a terapia oral, estimulação cerebral profunda e infusão enteral contínua de levodopa/carbidopa gel, e fornece instruções práticas de como iniciar o tratamento.

Palavras-chave: Apomorfina; dopaminérgicos; doença de Parkinson; revisão.

The management of Parkinson's disease (PD) aims for adequate control of motor and nonmotor symptoms, minimizing the adverse effects of medications ${ }^{1}$. A wide range of therapeutic options are available and can be used to tailor treatment to the needs of individual patients. These include dopamine replacement therapy using levodopa; direct stimulation of striatal dopamine receptors by dopamine agonists; and other interventions in dopamine metabolism using monoamine oxidase-B, DOPA decarboxylase or catecholO-methyltransferase inhibitors ${ }^{2}$. Despite being used since 1960, and enduring as the most powerful antiparkinsonian drug, levodopa is associated with a high incidence of motor complications ${ }^{3}$, with $24 \%$ to $89 \%$ of patients developing dyskinesias after long-term continuous exposure to this drug $\mathrm{g}^{4}$. There is debatable data on the role of dopamine agonists in postponing or minimizing these complications when used as monotherapy or in combination with lower doses of levodopa ${ }^{4}$. In addition, PD presents almost invariably with nonmotor symptoms that include mood and cognitive disorders (anxiety, depression, dementia and psychosis), autonomic dysfunction (urinary incontinence, constipation, dysphagia, gastroparesis, erectile dysfunction, orthostatic

\footnotetext{
${ }^{1}$ Associação Paranaense de Portadores de Parkinsonismo, Curitiba PR, Brasil;

${ }^{2}$ Faculdades Pequeno Príncipe, Departamento de Medicina, Curitiba PR, Brasil;

${ }^{3}$ University Health Network, Toronto Western Hospital, Morton and Gloria Shulman Movement Disorders Centre, Toronto ON, Canada;

«Universidade Federal do Paraná, Hospital de Clínicas, Serviço de Neurologia, Setor de Distúrbios do Movimento, Curitiba PR, Brasil;

EUniversity College of London, Institute of Neurology, London, UK.
}

Correspondence: Hélio A.G. Teive; Rua General Carneiro, 181; 80060-900 Curitiba PR, Brasil; E-mail: hagteive@mps.com.br

Conflict of interest: There is no conflict of interest to declare.

Received 02 June 2018; Received in final form 08 August 2018; Accepted 15 August 2018. 
hypotension, excessive sweating, drooling), pain, and sleep disturbances, that have a significant impact on quality of life, comparable or occasionally more severe than the motor aspects of the disease ${ }^{5}$.

Given the complexity of PD and its multiple layers of relevant clinical implications, it is quite common that, even with optimal therapy, some patients remain inadequately controlled, requiring invasive treatment ${ }^{2,6}$, i.e., deep brain stimulation (DBS), enterally-delivered levodopa/carbidopa gel and subcutaneous apomorphine $e^{3,5}$.

The objective of this review is to describe the current role of apomorphine in the treatment of PD.

\section{METHODS}

We performed a review of the literature based on review articles, expert opinion manuscripts and clinical trial reports from the PubMed database, using the following descriptors: apomorphine, Parkinson's disease, motor fluctuations, deep brain stimulation and intestinal levodopa/ carbidopa. The search was limited to articles published between 1984 and 2017.

\section{Historical review}

Apomorphine was the first dopamine agonist with powerful antiparkinsonian effects used in clinical practice ${ }^{2}$ and predated levodopa by ten years ${ }^{7-12}$. Derived from morphine, it was initially used as an emetic, expectorant, sedative, antipsychotic and anticonvulsant, as well as for managing drug and alcohol addiction (Figure 1$)^{8,13}$. Apomorphine is a highly-lipophilic, short-acting, nonergot dopamine agonist that acts on D1 and D2 dopamine receptors ${ }^{8,9,13,14}$. It was synthesized for the first time in 1869 by Matthiessen and Wright $^{9}$ and, although Weill recommended its use for PD in 1884, the first trials started in 1950, according Wenzel, ${ }^{9}$ Cotzias, ${ }^{15}$ and Lees ${ }^{16}$. In 1951, Schwab et al. ${ }^{17}$ observed

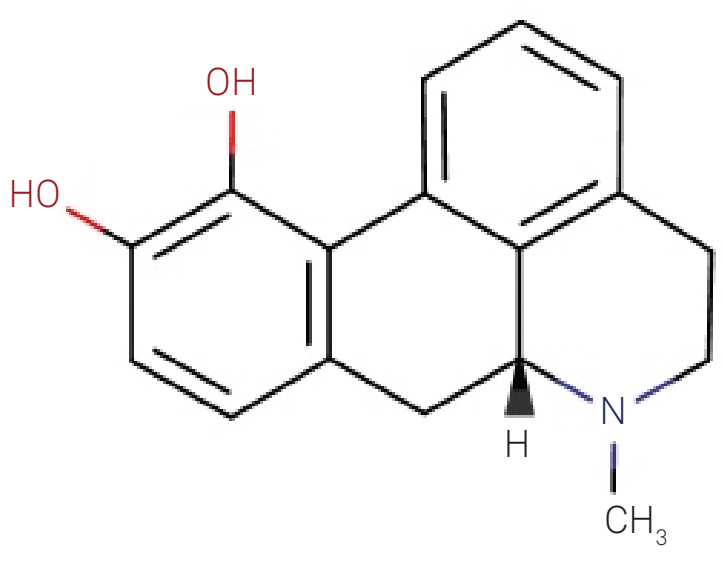

(Extracted from Google Images: Pharmajet, August 6, 2017)

Figure 1. Apomorphine: molecular structure. improvements in rigidity and tremor in $\mathrm{PD}$ patients 5-10 minutes after subcutaneous administration of a 0.5 to $1.0 \mathrm{mg}$ dose of apomorphine. These findings were later corroborated by Cotzias et al. ${ }^{13,15,16}$.

Oral administration of apomorphine required large doses to achieve the desired clinical response, and an exacerbated peripheral response was therefore common. This could include nausea, vomiting, postural hypotension and impaired kidney function, reflected in elevated urea and creatinine $^{16}$. Various administration routes were explored to avoid these adverse effects, the most successful of which proved to be the subcutaneous ${ }^{7,8,9,18,20,21,22}$.

Apomorphine is superior to other dopamine agonists such as lisuride because it has fewer adverse effects and induces significant improvement in motor and nonmotor symptoms, including hyperhidrosis, nocturia, urge incontinence, fatigue and mood disturbances, in addition to been well tolerated in patients with visual hallucinations, illusions and paranoid ideation ${ }^{23,24}$. It also improves sleep disorders, such as insomnia and restless legs syndrome, without worsening daytime drowsiness ${ }^{24}$.

In 1988, a group led by Lees, developed a mechanism for continuous subcutaneous apomorphine infusion, which was later routinely recommended for patients with severe, refractory "off" periods ${ }^{10}$. Although continuous apomorphine treatment was first introduced by Stibe et al. ${ }^{10}$ in 1988, subcutaneous injections were only approved by the FDA for use in motor "off" periods in $2004^{14}$. The long-term effectiveness of apomorphine as a rescue medication was also investigated in study APO302, in which 62 patients who had been having rescue injections for at least three months were assessed ${ }^{25}$. In a comparative assessment on the UPDRS scales, there was a significant reduction in motor score after 10 and 20 minutes ${ }^{25}$.

\section{Mechanism of action of apomorphine}

Apomorphine binds to pre- and postsynaptic receptors and exerts a therapeutic effect by direct stimulation of postsynaptic striatal dopamine D2 receptors, resulting in activation of the direct pathway and inactivation of the indirect striatopallidal pathways $s^{1,7,8,11,15,26,27}$. The motor response occurs after a single dose of subcutaneous apomorphine and is similar to that of levodopa but with faster onset (approximately 4-12 minutes), with a mean effect duration of 45-60 minutes ${ }^{1,16}$. In light of these therapeutic effects, it became one of the prototypic "rescue medications" in cases of unpredictable "off" periods, as in the case of patients with advanced PD and poorly-controlled motor fluctuations, who experience erratic gastric emptying $7,8,9,10,12,22,25,28,29,30,31,32$. Furthermore, it does not share transport mechanisms or metabolic pathways with levodopa and, unlike levodopa, does not require an active transport mechanism to reach the central nervous system ${ }^{7,8,9,10,18,28,31}$. Absorption varies with skin temperature and blood flow, and the best absorption is 
achieved when it is injected into the subcutaneous tissue of the abdominal wall. There is no interaction with cytochrome P450 inhibitors, and the cytochrome P450 system does not interfere with the metabolism of this dopamine agonist. Age, gender, disease duration, levodopa dosage or duration of apomorphine therapy do not appear to play any role in the clearance of the medication. ${ }^{11,23-25}$

\section{When should apomorphine be used?}

The first consideration for the use of apomorphine must be the confirmed diagnosis of levodopa-responsive $\mathrm{PD}^{1,11,33,34}$. Age is typically not a limiting factor, and mild cognitive impairment and axial symptoms are not contraindications. ${ }^{35,36,37,38,39}$ Indications for apomorphine include patients with refractory "off" periods, e.g., when there is a delay in the onset of the effects of orally administered medication; patients who have major "off" periods upon waking up; and

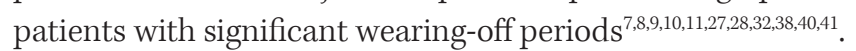
It can also improve nonmotor symptoms such as urinary disturbances ${ }^{3,24,35}$ and serve as a diagnostic clue when diagnosis of PD is uncertain ${ }^{1,18,33}$.

The therapeutic response to maximum levodopa doses does not vary in PD but is less consistent in patients with multiple system atrophy. Some patients with other parkinsonian syndromes are unresponsive or do not respond well to levodopa ${ }^{1,11,33}$. A study by the group led by Lees showed that apomorphine can be used as a diagnostic test of response to levodopa and has an accuracy of $90 \%^{1}$. The study concluded that a response to apomorphine supports a diagnosis of $\mathrm{PD}$, while failure to respond indicates that this diagnosis is extremely unlikely ${ }^{1}$.

\section{Routes of administration for apomorphine}

Various routes of administration have been investigated $^{8,11,19-22,27,40}$. Oral administration was first tried by Cotzias, who increased the dose gradually to $1,500 \mathrm{mg}$ a day ${ }^{15}$. Tolerance of 150 to $1,440 \mathrm{mg}$ daily doses was generally good, but higher doses caused azotemia $a^{7,10,11,39}$. The bioavailability of apomorphine administered by this route is less than $4 \%$ and this route was therefore considered unfeasible, as it required very high doses to achieve the desired effect, leading to significant side effects such as nephrotoxicity, reflected in elevated creatinine and urea ${ }^{11,18}$. Bioavailability of sublingual apomorphine is also low (10-22\%), and a $3 \mathrm{mg}$ subcutaneous dose and $30 \mathrm{mg}$ sublingual dose have similar pharmacological profiles and clinical responses ${ }^{11,27}$. Using this route, Ondo et al. ${ }^{42}$ reported an effect duration of between 60 and 130 minutes, while Hughes et al. ${ }^{29}$ reported a latency of up to 25 minutes and effect duration of 118 minutes. Apomorphine can cause nausea, orthostatic hypotension, an unpleasant taste and severe stomatitis, the latter being reported in about $50 \%$ of patients ${ }^{7,8,9,10,11,18,39}$. The intranasal spray has a pharmacokinetic profile similar to that of subcutaneously administered apomorphine but requires pretreatment with domperidone $e^{11,20,27,42,43}$. Latency to effect has been shown to be between 5 and 15 minutes, and the effect duration between 30 and 60 minutes ${ }^{11,20,27,43}$. In a study by Obering et al. ${ }^{27}$, the "off" period was significantly reduced from 5.3 hours/day to 3.8 hours/day. In another study on the use of apomorphine in $\mathrm{PD}$, no statistically significant difference was observed between levodopa and apomorphine in terms of the UPDRS score ${ }^{18}$.

\section{Intermittent apomorphine injection}

Ideally, the first dose should be administered in a hospital setting so that the clinical response can be observed and a tailored therapeutic dose identified ${ }^{1,6,11}$.

Peripheral dopaminergic adverse events can occur as a complication of injections of apomorphine, particularly nausea. Oral domperidone (10-20 mg three times a day, should be started one to three days before apomorphine therapy ${ }^{1,11}$ (Box 1).

Currently, penject (intermittent injection) and portable minipumps (continuous infusion) have been approved in most European countries (Figures 2 and 3), where they play an important role in advanced PD treatment and have yielded good results ${ }^{11,14,15,30,31,35}$. Hughes et al. ${ }^{1}$ published a study of 71 patients treated with intermittent injections (10/day) or continuous infusion (when more than 10 injections were needed). In 49 patients treated with intermittent injections, there was a $50 \%$ reduction in "off" time. After one year of treatment, $80 \%$ of the patients reported that the therapy was still effective ${ }^{1}$.

Intermittent infusion of apomorphine (penject) is performed with an insulin syringe mounted in an injector pen with premarked doses for ease of administration ${ }^{11,15,23}$. Injections sites can be administered in the abdominal region, arms and thighs ${ }^{11,12}$. The number of injections can vary between 1 and 30, and the dose can vary between $1 \mathrm{mg}$

1) Pretreatment with domperidone. (10-20 mg three times/ day, started one to three days before apomorphine therapy)

2) Performed when the patient has been off dopamine medication for 12-24 hours. Levodopa should be suspended the night before the test.

3) Measure blood pressure with the patient lying down, and seated, before the test.

4) Start with $1 \mathrm{mg}$ to $1.5 \mathrm{mg}$ subcutaneous apomorphine. Record the UPDRS-III score (pre- and post-apomorphine - ON, OFF) and any adverse effects (nausea, orthostatic hypotension, drowsiness, and dyskinesias).

5) Repeat administration of apomorphine at intervals of 1 to 1.5 hours, increasing the dose by $1 \mathrm{mg}$ until a good or acceptable clinical effect is observed.

No more than 7-8 mg per hour of apomorphine should be administered.

Box 1. Apomorphine test. 


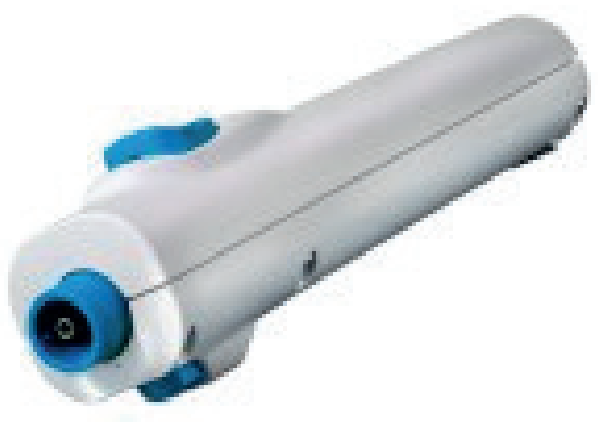

(Extracted from Google Images: Drugs.com, August 6, 2017) Figure 2. Apomorphine: penject.

and $10 \mathrm{mg}$ per injection ${ }^{11,23}$. Apomorphine solution is supplied at a concentration of $1 \mathrm{mg} / 0.1 \mathrm{~mL}$ in $3 \mathrm{~mL}$ (30 mg) glass cartridges with a manual reusable multidose injector pen that releases doses from $0.02 \mathrm{~mL}$ to $1 \mathrm{~mL}(10 \mathrm{mg})^{11,15,23}$. To minimize mistakes, the apomorphine dose should be prescribed in milliliters (rather than milligrams) as the injector pen uses this unit. An optimal therapeutic dose is between $0.3 \mathrm{~mL}$ and $0.5 \mathrm{~mL}$, or $3 \mathrm{mg}$ and $5 \mathrm{mg}^{11,23}$. Once a suitable dose has been identified, it rarely needs to be adjusted. The half-life of apomorphine is 45 minutes, and the minimum recommended time between injections is 60 minutes $^{11,23}$. The drug is absorbed quickly after subcutaneous injection, reaching maximum serum levels in 20 minutes, and the clinical effect can be observed between 5 and 15 minutes after administration ${ }^{11,13,23}$. Apomorphine is generally indicated for short periods. The mean daily dose is $3-30 \mathrm{mg} /$ day, and it is important to determine the dose required to reverse the "off" period ${ }^{11,23}$. Intermittent apomorphine infusion is a good rescue therapy in cases of motor fluctuations, such as wearing-off and on-off fluctuations, because of its fast action ${ }^{11,12,23}$. When required, apomorphine should be used as a rescue medication during "off" periods, without changing the levodopa schedule. It can reverse predictable and unpredictable "off" periods and is indicated when the "on" period is delayed ${ }^{11,15,23}$. It helps with morning or nocturnal akinesia as well as painful dystonias, and is a suitable choice when absorption of orally administered levodopa is hampered by delayed gastric emptying ${ }^{11,12,23}$. Apomorphine can also improve psychiatric symptoms such as depression and panic attacks ${ }^{24}$. Some surgical centers use apomorphine administered by penject as a rescue medication in preoperative patients when oral medication cannot be administered ${ }^{11,23}$.

\section{Continuous apomorphine infusion}

An infusion pump is recommended when "off" periods are poorly controlled by oral treatment or when apomorphine injections are effective but required more frequently (more than 4-6 times a day) ${ }^{11,23,44,45}$. The patient can be kept

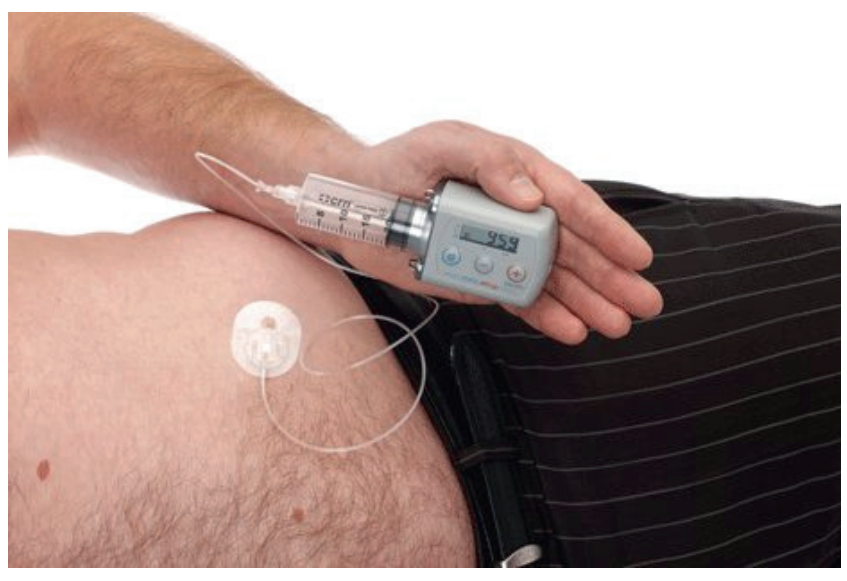

(Courtesy Prof. Andrew Lees.)

Figure 3. Apomorphine: pump.

1) Hemolytic anemia

2) ECG changes (prolonged QT, atrial fibrillation, tachycardia, bradyarrhythmias, premature ventricular contractions)

3) Use of anticoagulants

4) Diabetes and other diseases that inhibit healing of surgical wounds

5) Cellulite and other local infections

6) Hypersensitivity to apomorphine or components of the formulation, such as sodium metabisulfite.

7) Severe psychiatric symptoms.

Box 2. Contraindications for apomorphine.

in a continuous "on" state with an improvement in dyskinesias, and the levodopa dose can be reduced ${ }^{11,23,36}$. Like intermittent infusion, continuous infusion of apomorphine helps nonmotor symptoms such as pain and mood swings. This form of administration is recommended for patients in whom duodenal levodopa infusion and DBS are contraindicated. Of the options available for advanced stages of the disease, it is the least invasive ${ }^{36}$. Unlike with DBS, age and neuropsychiatric changes are not absolute contraindications for apomorphine infusion ${ }^{11,46,47}$. Continuous apomorphine infusion is also an alternative to oral treatment, which is complex and may have limited adherence or may not result in adequate absorption, as it minimizes drug interactions when the patient is taking several medications ${ }^{6,11,23}$. Various studies have shown that the levodopa dose can be reduced by between $16 \%$ and $18 \%$ after apomorphine is started ${ }^{1,11,23}$. Apomorphine can also reduce the "off" period by $50 \%$ to $80 \%$ and guarantees patient mobility during the day even in the absence of levodopa ${ }^{6,11,23}$.

The initial assessment should include an electrocardiogram to exclude the presence of a long QT interval, 
tachycardia, bradyarrhythmias, atrial fibrillation and premature ventricular contractions, and should exclude pre-existing hemolytic anemia ${ }^{4,11}$. Box 2 shows the main contraindications for use of apomorphine.

One day before starting apomorphine treatment, patients should be pretreated with $10 \mathrm{mg}$ of domperidone, which can be discontinued as soon as possible, when the adverse effects of apomorphine have been controlled ${ }^{6,11}$. The teflon delivery needle is inserted in the subcutaneous tissue of the abdominal wall, and the site is changed at least every day. Continuous infusion is usually started in a hospital setting, with a flow rate of 0.5 or $1 \mathrm{mg} /$ hour during the first day. The infusion cycle is generally 12-24 hours a day (typically 16 hours), and the usual dose is $4-7 \mathrm{mg} /$ hour $^{11,46}$. The hourly flow rate is adjusted depending on its effectiveness and patient tolerability. Generally, the rate is increased by $0.5-1.0 \mathrm{mg} /$ hour every day during the initial period and more slowly after that at weekly intervals. Some patients are encouraged to use a booster dose in anticipation of "off" periods ${ }^{11,46}$.

In patients being treated with continuous subcutaneous infusion of apomorphine, oral dopamine agonists can gradually be discontinued during the apomorphine titration period ${ }^{12}$. Sudden interruption of these agonists can lead to dopamine agonist withdrawal syndrome ${ }^{11,12}$. Other antiparkinsonian medications (monoamine oxidase-B inhibitors, catechol-O-methyltransferase inhibitors, amantadine, anticholinergics) should then be discontinued gradually, usually in the first seven days ${ }^{11,12}$. Levodopa is generally reduced when the desired therapeutic dose of apomorphine is reached but can be reduced when apomorphine is started if dyskinesia is present $\mathrm{t}^{11,12,37}$.

\section{Adverse events}

The most common long-term side effect, which occurs in up to $70 \%$ of individuals, is nodules at the injection site ${ }^{11,14}$. Some patients may develop itching, bruising or pain. These local adverse effects are related to drug concentration, infusion time or injection depth ${ }^{11,14}$. In some patients (10-20\%) reactions may be more severe, and necrotic nodular ulcerations or panniculitis may occur. This can be solved by rotating the injection site every day, ensuring asepsis, applying silicone gel patches or, in some cases, it may be necessary to use ultrasound treatment ${ }^{11,14}$. García Ruiz et al. ${ }^{40}$ found that sedation occurred in $29 \%$ of patients using an apomorphine pump. Orthostatic hypotension can be a manifestation of dysautonomia or due to dopamine stimulation and can be improved with domperidone. In some cases, patients may need to wear compression stockings, keep their legs raised and take salt tablets or even fludrocortisone together with midodrine ${ }^{11,12}$. Hematological tests at regular intervals are recommended to avoid the risk of hemolytic anemia ${ }^{11,12}$.

Electrocardiographic changes (QT prolongation) can occur with doses of $6 \mathrm{mg}$ or more. Prophylactic treatment with dopamine antagonists (e.g., metoclopramide and prochlorperazine) and serotonin receptor antagonists (e.g., granisetron and ondansetron) should be avoided because these agents cross the blood-brain barrier and can interact with apomorphine $e^{6,11}$. When used with ondansetron, apomorphine can cause severe hypotension and loss of consciousness ${ }^{6,11}$. Concomitant use of 5-HT3 antagonists is contraindicated. Doses of more than $6 \mathrm{mg}$ do not lead to additional benefits and are not recommended ${ }^{11,12}$.

Table 1 summarizes the main adverse effects of subcutaneous apomorphine.

\section{Conventional oral treatment vs. apomorphine}

The quality of the response to oral levodopa is indistinguishable from the quality of the response to apomorphine ${ }^{11,16}$. Apomorphine, however, produces a shorter motor response, supporting the idea that the integrity of the postsynaptic receptors is the key factor that determines the dopamine response in Parkinson's disease treatment. In other words, the clinical responses to the drugs are the same although they have different mechanisms of action ${ }^{11,16}$.

Apomorphine has various advantages over levodopa, such as the fact that it is a monotherapy and increases the "on" period by maintaining a continuous dopamine stimulus, reducing the need for levodopa and, in turn, reducing dyski-

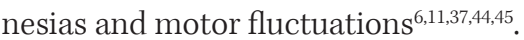

As it is administered parenterally, apomorphine improves treatment adherence in patients who cannot tolerate oral medicine or in whom absorption is erratic ${ }^{6,11}$. However, it requires help from relatives or caregivers to handle the pump. Furthermore, apomorphine crosses the blood-brain barrier quickly without depending on an active transport system and without competing with proteins in the circulation ${ }^{1,11}$.

\section{Other device-aided therapy strategies vs. apomorphine}

Deep brain stimulation is currently widely accepted as an alternative in stages of PD when motor complications

Table 1. Adverse effects associated with apomorphine.

\begin{tabular}{lr}
\hline Local & Subcutaneous nodules, local allergy, panniculitis. \\
\hline Systemic & Fatigue, nausea, dizziness, orthostatic hypotension and mental confusion, yawning. \\
Hematological & Hemolytic anemia. \\
Psychiatric & Psychosis (associated with the patient's cognitive decline and disease duration and severity), dopamine \\
dysregulation syndrome and impulse control disorder.
\end{tabular}


are significant, or the symptoms of the disease are not well controlled $^{37,38,47}$. Deep brain stimulation of the subthalamic nucleus and apomorphine infusion produces significant improvements in parkinsonian symptoms and motor fluctuations through different mechanisms ${ }^{2,11,38,39,47}$. The choice of therapy depends on the profiles of individual patients. Although the surgical procedure is considered relatively safe, it obviously is not risk-free and potential adverse effects of DBS include hypophonia and other bulbar symptoms, behavioral and cognitive changes, infections, transient confusion, seizures, intracranial bleeding, and various forms of hardware dysfunction ${ }^{11,38,47,48}$. For example, a Spanish study that compared DBS and treatment with apomorphine showed that neuropsychological testing for the apomorphine group did not change, while for the patients who underwent DBS surgery, verbal phonemic fluency and word-naming speed were affected negatively ${ }^{47}$. Additionally, apomorphine infusion therapies can be used in patients with severe cognitive impairment and psychiatric disorders. Borgemeester et al. published a retrospective, long-term follow-up study about continuous subcutaneous apomorphine infusion in PD patients with cognitive dysfunction. ${ }^{49}$ The study demonstrated that apomorphine infusion is an effective treatment in advanced PD patients with cognitive dysfunction, including visual hallucinations and orthostatic hypotension. ${ }^{49}$ Combined use of DBS and an apomorphine pump can be considered in patients with adverse effects on axial functions, such as altered gait or dysarthria ${ }^{47,50}$.

Continuous enteral infusion of levodopa/carbidopa gel (LCIG) was tested in small studies published in $1986^{51}$ and $1988^{52}$, and then in a long-term study developed at the University of Uppsala, Sweden ${ }^{53}$, as a therapeutic alternative for the advanced stage of the disease. It is a combination of levodopa $(20 \mathrm{mg} / \mathrm{mL})$ and carbidopa $(5 \mathrm{mg} / \mathrm{mL})$ in a pseudoplastic gel and is delivered directly into the proximal jejunum by means of a portable infusion pump and duodenal catheter $^{11,53}$. It has the advantage that it ensures a stable flow of dopamine into the striatum and, consequently, an increase in "on" time without dyskinesias ${ }^{11,53}$. It also improves nonmotor symptoms such as drowsiness, fatigue, impaired attention, memory loss, and gastrointestinal, urinary and cardiovascular problems ${ }^{53}$. Ricciardi et al..$^{54}$ evaluated 24-hour infusion of LCIG in eight PD patients to address severe nocturnal dyskinesia unresponsive to oral therapies. They found significant improvements in fatigue and sleep quality, mood/cognition, hallucinations, and urinary function, and there was no change in motor severity or motor complications. The most common adverse effect is dyskinesia, although this is less common than with oral treatment ${ }^{2,28,53,55}$. Long-term use of high doses of levodopa leads to increased homocysteine levels and reduced cobalamin metabolism. The risk of severe infections such as peritonitis is low. Nevertheless, such infections, if they occur,

Table 2. Comparison of the different treatment options.

\begin{tabular}{|c|c|c|c|c|}
\hline Variable & Indication & Advantages of the procedure & $\begin{array}{l}\text { Disadvantages of } \\
\text { the procedure }\end{array}$ & Adverse effects \\
\hline \multirow[t]{3}{*}{$\begin{array}{l}\text { Deep brain } \\
\text { stimulation }\end{array}$} & \multirow[t]{3}{*}{$\begin{array}{c}\text { The best option in cases of } \\
\text { dyskinesia }\end{array}$} & Less need for dopamine medication & \multirow[t]{3}{*}{$\begin{array}{l}\text { Invasive therapy with } \\
\text { surgical risks such } \\
\text { as hemorrhage and } \\
\text { infection }\end{array}$} & \multirow[t]{3}{*}{$\begin{array}{c}\text { Worsening of } \\
\text { neuropsychiatric function, } \\
\text { cognitive changes } \\
\text { Can lead to worsening of } \\
\text { speech, postural instability } \\
\text { and freezing of gait }\end{array}$} \\
\hline & & Non-ablative & & \\
\hline & & Better for refractory tremor & & \\
\hline \multirow{3}{*}{ Apomorphine } & $\begin{array}{l}\text { Rescue from "off" } \\
\text { episodes }\end{array}$ & Mildly invasive & $\begin{array}{l}\text { Frequent blood tests } \\
\text { and ECG are required }\end{array}$ & \multirow{3}{*}{$\begin{array}{c}\text { Local, systemic, } \\
\text { hematological and } \\
\text { psychiatric (see Table 1) }\end{array}$} \\
\hline & \multirow[t]{2}{*}{ Motor fluctuations } & $\begin{array}{l}\text { Parenteral administration (important } \\
\text { for patients who cannot tolerate oral } \\
\text { medication or have poor absorption) }\end{array}$ & $\begin{array}{l}\text { Requires relatives or } \\
\text { caregivers to handle } \\
\text { the pump }\end{array}$ & \\
\hline & & $\begin{array}{l}\text { Crosses the blood-brain barrier } \\
\text { quickly without any need for active } \\
\text { transport and without competing } \\
\text { with proteins in the circulation. }\end{array}$ & & \\
\hline \multirow{4}{*}{$\begin{array}{l}\text { Jejunal } \\
\text { levodopa-carbidopa }\end{array}$} & $\begin{array}{l}\text { Frequent "off" periods or } \\
\text { severe dyskinesia }\end{array}$ & $\begin{array}{c}\text { More physiological release of } \\
\text { dopamine and less pulsatile stimulus }\end{array}$ & $\begin{array}{l}\text { Can worsen } \\
\text { dyskinesia }\end{array}$ & \multirow{4}{*}{$\begin{array}{l}\text { Peripheral } \\
\text { polyneuropathy }\end{array}$} \\
\hline & $\begin{array}{l}\text { When DBS and } \\
\text { apomorphine are } \\
\text { contraindicated, ineffective } \\
\text { or inappropriate }\end{array}$ & Less invasive than DBS & \multirow[t]{3}{*}{$\begin{array}{l}\text { Can cause anxiety, } \\
\text { depression, } \\
\text { hallucination and } \\
\text { confusion }\end{array}$} & \\
\hline & $\begin{array}{l}\text { Can improve postural } \\
\text { problems and produce } \\
\text { some response in gait }\end{array}$ & Safe. & & \\
\hline & & $\begin{array}{c}\text { No age limit; mild and moderate } \\
\text { dementia are not contraindications }\end{array}$ & & \\
\hline
\end{tabular}


can lead to death ${ }^{53,55}$. Other adverse effects may include skin problems at the surgical site, weight loss and peripheral axonal neuropathy, the mechanism of which is poorly understood ${ }^{53}$. There are small trials comparing apomorphine infusion and LCIG, showing that the apomorphine pump is easier for caregivers and patients to use, and is less expensive ${ }^{56-58}$. However, if apomorphine infusion does not yield satisfactory results, jejunal levodopa may be indicated ${ }^{11,12,58}$.

The choice of apomorphine or LCIG depends on the individual patient and should take into account the adverse effects and technical aspects of each therapy ${ }^{11,12,58,59}$. The expert consensus groups recognize the rapid and consistent relief from the symptoms of PD provided by apomorphine. Its mode of delivery is less invasive than DBS or LCIG, other therapies also considered for the treatment of this stage of the disease. Also, apomorphine infusion can be easily and immediately reversed, either when adverse effects occur or at the patient's request ${ }^{60}$. Table 2 summarizes the main therapies discussed here.

\section{CONCLUSION}

Apomorphine is a treatment option for advanced Parkinson's disease that is well tolerated and optimizes motor fluctuations and nonmotor symptoms frequently found in the condition. It is another treatment option that can be used to improve the patient's quality of life.

\section{References}

1. Hughes AJ, Lees AJ, Stern GM. The motor response to sequential apomorphine in parkinsonian fluctuations. J Neurol Neurosurg Psychiatry. 1991 Apr;54(4):358-60. https://doi.org/10.1136/jnnp.54.4.358

2. Kulisevsky J, Luquin MR, Arbelo JM, Burguera JA, Carrillo F, Castro A et al. [Advanced Parkinson's disease: clinical characteristics and treatment (part 1)]. Neurologia. 2013 Oct;28(8):503-21. Spanish. https://doi.org/10.1016/j.nrl.2013.05.001

3. Kieburtz K. Therapeutic strategies to prevent motor complications in Parkinson's disease.J Neurol. 2008 Aug;255(S4 Suppl 4):42-5. https://doi.org/10.1007/s00415-008-4007-4

4. Odin P, Ray Chaudhuri K, Slevin JT, Volkmann J, Dietrichs E, Martinez-Martin P et al. Collective physician perspectives on non-oral medication approaches for the management of clinically relevant unresolved issues in Parkinson's disease: consensus from an international survey and discussion program. Parkinsonism Relat Disord. 2015 Oct;21(10):1133-44 https://doi.org/10.1016/j.parkreldis.2015.07.020

5. Barboza JL, Okun MS, Moshiree B. The treatment of gastroparesis, constipation and small intestinal bacterial overgrowth syndrome in patients with Parkinson's disease. Expert Opin Pharmacother. 2015;16(16):2449-64.https://doi.org/10.1517/14656566.2015.1086747

6. Krüger R, Hilker R, Winkler C, Lorrain M, Hahne M, Redecker C et al. Advanced stages of PD: interventional therapies and related patientcentered care. J Neural Transm (Vienna). 2016 Jan;123(1):31-43. https://doi.org/10.1007/s00702-015-1418-0

7. O'Sullivan JD, Lees AJ. Use of apomorphine in Parkinson's disease. Hosp Med. 1999 Nov;60(11):816-20. https://doi.org/10.12968/hosp.1999.60.11.1236

8. Frankel JP, Lees AJ, Kempster PA, Stern GM. Subcutaneous apomorphine in the treatment of Parkinson's disease.J Neurol Neurosurg Psychiatry. 1990 Feb;53(2):96-101. https://doi.org/10.1136/jnnp.53.2.96

9. Hardie RJ, Lees AJ, Stern GM. On-off fluctuations in Parkinson's disease: a clinical and neuropharmacological study. Brain. 1984 Jun;107(Pt 2):487-506. https://doi.org/10.1093/brain/107.2.487

10. Stibe CM, Lees AJ, Kempster PA, Stern GM. Subcutaneous apomorphine in parkinsonian on-off oscillations. Lancet. 1988 Feb;1(8582):403-6. https://doi.org/10.1016/S0140-6736(88)91193-2

11. Hagell P, Odin P. Apomorphine in Parkinson's disease. 3rd ed. Bremen: UNI-MED; 2014

12. Djamshidian A, Poewe W. Apomorphine and levodopa in Parkinson's disease: two revolutionary drugs from the 1950's. Parkinsonism Relat Disord. 2016 Dec;33 Suppl 1:S9-12. https://doi.org/10.1016/j.parkreldis.2016.12.004
13. Hilker R, Antonini A, Odin P. What is the best treatment for fluctuating Parkinson's disease: continuous drug delivery or deep brain stimulation of the subthalamic nucleus? J Neural Transm (Vienna). 2011 Jun;118(6):907-14. https://doi.org/10.1007/s00702-010-0555-8

14. Wenzel K, Homann CN, Fabbrini G, Colosimo C. The role of subcutaneous infusion of apomorphine in Parkinson's disease. Expert Rev Neurother. 2014 Jul;14(7):833-43. https://doi.org/10.1586/14737175.2014.928202

15. Cotzias GC, Papavasiliou PS, Fehling C, Kaufman B, Mena I. Similarities between neurologic effects of L-dopa and of apomorphine. N Engl J Med. 1970 Jan;282(1):31-3. https://doi.org/10.1056/NEJM197001012820107

16. Lees AJ. Dopamine agonists in Parkinson's disease: a look at apomorphine. Fundam Clin Pharmacol. 1993;7(3-4):121-8. https://doi.org/10.1111/j.1472-8206.1993.tb00226.x

17. Schwab RS, Amador LV, Lettvin JY. Apomorphine in Parkinson's disease. Trans Am Neurol Assoc. 1951;56:251-3.

18. Henriksen T. Clinical insights into use of apomorphine in Parkinson's disease: tools for clinicians. Neurodegener Dis Manag. 2014;4(3):271-82. https://doi.org/10.2217/nmt.14.17

19. Hughes AJ, Bishop S, Lees AJ, Stern GM, Webster R, Bovingdon M. Rectal apomorphine in Parkinson's disease. Lancet. 1991 Jan;337(8733):118. https://doi.org/10.1016/0140-6736(91)90780-S

20. Kleedorfer B, Turjanski N, Ryan R, Lees AJ, Milroy C, Stern GM. Intranasal apomorphine in Parkinson's disease. Neurology. 1991 May;41(5):761-2. https://doi.org/10.1212/WNL.41.5.761-a

21. Hughes AJ, Webster R, Bovingdon M, Lees AJ, Stern GM. Sublingual apomorphine in the treatment of Parkinson's disease complicated by motor fluctuations. Clin Neuropharmacol. 1991 Dec;14(6):556-61. https://doi.org/10.1097/00002826-199112000-00008

22. Manson AJ, Hanagasi H, Turner K, Patsalos PN, Carey P, Ratnaraj $\mathrm{N}$ et al. Intravenous apomorphine therapy in Parkinson's disease: clinical and pharmacokinetic observations. Brain. 2001 Feb;124(Pt 2):331-40. https://doi.org/10.1093/brain/124.2.331

23. Martinez-Martin P, Reddy P, Antonini A, Henriksen T, Katzenschlager R, Odin P et al. Chronic subcutaneous infusion therapy with apomorphine in advanced Parkinson's disease compared to conventional therapy: a real life study of non motor effect. J Parkinsons Dis. 2011;1(2):197-203.

24. Menon R, Stacy M. Apomorphine in the treatment of Parkinson's disease. Expert Opin Pharmacother. 2007 Aug;8(12):1941-50. https://doi.org/10.1517/14656566.8.12.1941 
25. Pfeiffer RF, Gutmann L, Hull KL Jr, Bottini PB, Sherry $\mathrm{JH}$. Continued efficacy and safety of subcutaneous apomorphine in patients with advanced Parkinson's disease. Parkinsonism Relat Disord. 2007 Mar;13(2):93-100. https://doi.org/10.1016/j.parkreldis.2006.06.012

26. Ramirez-Zamora A, Molho E. Treatment of motor fluctuations in Parkinson's disease: recent developments and future directions. Expert Rev Neurother. 2014 Jan;14(1):93-103. https://doi.org/10.1586/14737175.2014.868306

27. Obering CD, Chen JJ, Swope DM. Update on apomorphine for the rapid treatment of hypomobility ("off") episodes in Parkinson's disease. Pharmacotherapy. 2006 Jun;26(6):840-52. https://doi.org/10.1592/phco.26.6.840

28. Kempster PA, Frankel JP, Stern GM, Lees AJ. Comparison of motor response to apomorphine and levodopa in Parkinson's disease. J Neurol Neurosurg Psychiatry. 1990 Nov;53(11):1004-7. https://doi.org/10.1136/jnnp.53.11.1004

29. Hughes AJ, Bishop S, Stern GM, Lees AJ. The motor response to repeated apomorphine administration in Parkinson's disease. Clin Neuropharmacol. 1991 Jun;14(3):209-13. https://doi.org/10.1097/00002826-199106000-00003

30. Hughes AJ, Bishop S, Kleedorfer B, Turjanski N, Fernandez W, Lees AJ et al. Subcutaneous apomorphine in Parkinson's disease: response to chronic administration for up to five years. Mov Disord. 1993 Apr;8(2):165-70. https://doi.org/10.1002/mds.870080208

31. Colosimo C, Merello M, Hughes AJ, Sieradzan K, Lees AJ. Motor response to acute dopaminergic challenge with apomorphine and levodopa in Parkinson's disease: implications for the pathogenesis of the on-off phenomenon. J Neurol Neurosurg Psychiatry. 1996 Jun;60(6):634-7. https://doi.org/10.1136/jnnp.60.6.634

32. Manson AJ, Turner K, Lees AJ. Apomorphine monotherapy in the treatment of refractory motor complications of Parkinson's disease: long-term follow-up study of 64 patients. Mov Disord. 2002 Nov;17(6):1235-41. https://doi.org/10.1002/mds.10281

33. Hughes AJ, Lees AJ, Stern GM. Apomorphine test to predict dopaminergic responsiveness in parkinsonian syndromes. Lancet. 1990 Jul;336(8706):32-4 https://doi.org/10.1016/0140-6736(90)91531-E

34. Hughes AJ, Lees AJ, Stern GM. Apomorphine in the diagnosis and treatment of parkinsonian tremor. Clin Neuropharmacol. 1990 Aug;13(4):312-7. https://doi.org/10.1097/00002826-199008000-00005

35. Gunzler SA. Apomorphine in the treatment of Parkinson disease and other movement disorders. Expert Opin Pharmacother. 2009 Apr;10(6):1027-38. https://doi.org/10.1517/14656560902828344

36. Pietz K, Hagell P, Odin P. Subcutaneous apomorphine in late stage Parkinson's disease: a long term follow up. J Neurol Neurosurg Psychiatry. 1998 Nov;65(5):709-16. https://doi.org/10.1136/jnnp.65.5.709

37. Merola A, Espay AJ, Romagnolo A, Bernardini A, Rizzi L, Rosso $M$ et al. Advanced therapies in Parkinson's disease: long-term retrospective study. Parkinsonism Relat Disord. 2016 Aug;29:104-8. https://doi.org/10.1016/j.parkreldis.2016.05.015

38. Ossig C, Reichmann H. Treatment of Parkinson's disease in the advanced stage. J Neural Transm (Vienna). 2013 Apr;120(4):523-9. https://doi.org/10.1007/s00702-013-1008-y

39. Sesar Á, Fernández-Pajarín G, Ares B, Rivas MT, Castro A. Continuous subcutaneous apomorphine infusion in advanced Parkinson's disease: 10-year experience with 230 patients. J Neurol. 2017 May;264(5):946-54. https://doi.org/10.1007/s00415-017-8477-0

40. García Ruiz PJ, Sesar Ignacio A, Ares Pensado B, Castro García A, Alonso Frech F, Alvarez López M et al. Efficacy of long-term continuous subcutaneous apomorphine infusion in advanced Parkinson's disease with motor fluctuations: a multicenter study. Mov Disord. 2008 Jun;23(8):1130-6. https://doi.org/10.1002/mds.22063

41. Colosimo C, Merello M, Hughes AJ, Sieradzan K, Lees AJ. Apomorphine responses in Parkinson's disease and the pathogenesis of motor complications. Neurology. 1998 Feb;50(2):573-4. https://doi.org/10.1212/WNL.50.2.573-b

42. Ondo WG, Hunter C, Ferrara JM, Mostile G. Apomorphine injections: predictors of initial common adverse events and long term tolerability. Parkinsonism Relat Disord. 2012 Jun;18(5):619-22. https://doi.org/10.1016/j.parkreldis.2012.01.001

43. Kapoor R, Turjanski N, Frankel J, Kleedorfer B, Lees A, Stern G et al. Intranasal apomorphine: a new treatment in Parkinson's disease.J Neurol Neurosurg Psychiatry. 1990 Nov;53(11):1015. https://doi.org/10.1136/jnnp.53.11.1015

44. Colzi A, Turner K, Lees AJ. Continuous subcutaneous waking day apomorphine in the long term treatment of levodopa induced interdose dyskinesias in Parkinson's disease. J Neurol Neurosurg Psychiatry. 1998 May;64(5):573-6. https://doi.org/10.1136/jnnp.64.5.573

45. Katzenschlager R, Hughes A, Evans A, Manson AJ, Hoffman M, Swinn L et al. Continuous subcutaneous apomorphine therapy improves dyskinesias in Parkinson's disease: a prospective study using single-dose challenges. Mov Disord. 2005 Feb;20(2):151-7. https://doi.org/10.1002/mds.20276

46. Borgemeester RW, Lees AJ, Laar T. Parkinson's disease, visual hallucinations and apomorphine: a review of the available evidence. Parkinsonism Relat Disord. 2016 Jun;27:35-40. https://doi.org/10.1016/j.parkreldis.2016.04.023

47. Alegret M, Valldeoriola F, Martí M, Pilleri M, Junqué C, Rumià $J$,- et al. Comparative cognitive effects of bilateral subthalamic stimulation and subcutaneous continuous infusion of apomorphine in Parkinson's disease. Mov Disord. 2004 Dec;19(12):1463-9. https://doi.org/10.1002/mds.20237

48. Auffret M, Le Jeune F, Maurus A, Drapier S, Houvenaghel JF, Robert GH,- et al. Apomorphine pump in advanced Parkinson's disease: effects on motor and nonmotor symptoms with brain metabolism correlations. J Neurol Sci. 2017 Jan;372:279-87. https://doi.org/10.1016/j.jns.2016.11.080

49. Borgemeester RW, Laar T. Continuous subcutaneous apomorphine infusion in Parkinson's disease patients with cognitive dysfunction: A retrospective long-term followup study. Parkinsonism Relat Disord. 2017 Dec;45:33-8. https://doi.org/10.1016/j.parkreldis.2017.09.025

50. Chauduri KR, Qamar MA, Rajah T, Loehrer P, Sauerbier A, Odin P, Jenner P. Non-oral dopaminergic therapies for Parkinson's disease: current treatments and the future. NPJ Parkinsons Disease. 2016 Dec 1;2:16023. https://doi.org/10.1038/npjparkd.2016.23 eCollection 2016.

51. Kurlan R, Rubin AJ, Miller C, Rivera-Calimlim L, Clarke A, Shoulson I. Duodenal delivery of levodopa for on-off fluctuations in parkinsonism: preliminary observations. Ann Neurol. 1986 Aug;20(2):262-5. https://doi.org/10.1002/ana.410200213

52. Sage JI, Trooskin S, Sonsalla PK, Heikkila R, Duvoisin RC. Long-term duodenal infusion of levodopa for motor fluctuations in parkinsonism. Ann Neurol. 1988 Jul;24(1):87-9. https://doi.org/10.1002/ana.410240116

53. Nilsson D, Nyholm D, Aquilonius SM. Duodenal levodopa infusion in Parkinson's disease: long-term experience. Acta Neurol Scand. 2001 Dec;104(6):343-8. https://doi.org/10.1034/j.1600-0404.2001.00153.xPMID:11903087

54. Ricciardi L, Bove F, Espay K, Lena F, Modugno N, Poon YY et al. 24-Hour infusion of levodopa/carbidopa intestinal gel for nocturnal akinesia in advanced Parkinson's disease. Mov Disord. 2016 Apr;31 (4):597-8. https://doi.org/10.1002/mds.26564 
55. Antonini A, Isaias IU, Canesi M, Zibetti M, Mancini F, Manfredi L et al. Duodenal levodopa infusion for advanced Parkinson's disease: 12-month treatment outcome. Mov Disord. 2007 Jun;22(8):1145-9. https://doi.org/10.1002/mds.21500

56. Nyholm D, Constantinescu R, Holmberg B, Dizdar N, Askmark H. Comparison of apomorphine and levodopa infusions in four patients with Parkinson's disease with symptom fluctuations. Acta Neurol Scand. 2009 May;119(5):345-8. https://doi.org/10.1111/j.1600-0404.2008.01104.x

57. Klostermann F, Jugel C, Marzinzik F. Benefit from jejunal levodopa in a patient with apomorphine pump.J Neurol. 2011 Feb;258(2):311-2. https://doi.org/10.1007/s00415-010-5698-x

58. Elia AE, Dollenz C, Soliveri P, Albanese A. Motor features and response to oral levodopa in patients with Parkinson's disease under continuous dopaminergic infusion or deep brain stimulation. Eur J Neurol. 2012 Jan;19(1):76-83. https://doi.org/10.1111/j.1468-1331.2011.03437.x

59. Volkmann J, Albanese A, Antonini A, Chaudhuri KR, Clarke $\mathrm{CE}$, Bie RM et al. Selecting deep brain stimulation or infusion therapies in advanced Parkinson's disease: an evidence-based review. J Neurol. 2013 Nov;260(11):2701-14. https://doi.org/10.1007/s00415-012-6798-6

60. Trenkwalder C, Chaudhuri KR, García Ruiz PJ, LeWitt P, Katzenschlager R, Sixel-Döring F et al.. Expert Consensus Group report on the use of apomorphine in the treatment of Parkinson's disease: clinical practice recommendations. Parkinsonism Relat Disord. 2015 Sep;21(9):1023-30. https://doi.org/10.1016/j.parkreldis.2015.06.012 